thing of real value. The motion pictures are not to be regarded as a means of teaching, but rather as a means of contributing a background that will hold the discussion closer to the real facts of the case, and for that reason enhance its value."

The Harvard University Film Foundation has coöperated in an effort to acquire films which are best suited to the purpose. Most of the films have been secured from manufacturing concerns and had been made originally for advertising purposes. Members of the Society have already made many contributions which have augmented the picture collection at Baker Library, and some may now know of other collections of industrial pictures that have served their purpose in advertising or elsewhere, which might, through the Society, be made available to the Business School.

\title{
Legal Documents and Business History
}

Since the founding of the Society there has accumulated in its possession a large number of legal documents. These vary greatly in type and value. Among them may be found deeds, leases, business agreements such as articles of copartnership, etc., apprentice agreements, and wills. As it might be expected, those documents which throw some light on the customs of the people in the wide field of human relations are of the greatest value, and yet it is often difficult to follow a logical and reasonable standard in collecting such material.

Doubtless in the experience of every library are to be found instances of the accumulation of some particular type of material, having little value and yet possessing characteristics that almost defy the decision to destroy. Deeds fall into this class. This must not be taken to mean such documents as are tied in with collections - they are often of unquestioned value - but isolated deeds of small parcels of land probably can never be of much use. Also deeds are usually recorded and easily available in the public records, which further makes it unnecessary to collect them.

It is really their age and their beauty that commands respect and preserves them from destruction. They comprise some of the oldest material in the possession of the Society. The indenture shown in the accompanying illustration is an English document dating back to 1687 " in the third year of the Reign of our Sovereign Lord James the Second By the Grace of God of England Scotland 
France and Ireland king" etc. The document contains some fifteen hundred words and sets forth a rather involved agreement of minor importance concerning the transfer of property. When one attempts to fathom the intricacies of its long lines, one is tempted to agree with Adam Smith's explanation: "It has been the custom in modern Europe to regulate, upon most occasions, the payment of attorneys and clerks of court according to the number of pages which they had to write; the court, however, requiring that each page should contain so many lines, and each line so many words. In order to increase their payment, the attorneys and clerks have contrived to multiply words beyond all necessity, to the corruption of the law language of, I believe, every court of justice in Europe."

But look at the first two words "This Indenture." They are exquisite and can never allow the document to be destroyed, however unimportant the agreement which follows. Then, further, many of these old documents are written on most beautiful parchment, another point in favor of their preservation.

Leases are often of more interest. Note the amusing wording of the following transcript:

\section{KNOW ALL MEN BY THESE PRESENTS}

That we Sprake Livingstone and Benjamin Livingstone of Chelmstord in the County of Middlesix and Commonwealth of Massachusetts, Carpenters, Doth, Agree to Let Unto Timothy Coburn Jur in the above said town, his heirs or assigns, A House Situated in Chelmsford formily Owned by Seth Livingstone Deceased, as follows Viz .... .

The Southeast room in the said House with the Chamber and Garrit above the Said room and Cetching ajorning the Same room and to Use the oven in the Cetching When not in Use by the oner and the Well of warter near the house and the Sullar under Said room Reserving room in the Sullar for the Widdow Abigal Livingstone to put in her Sass and Cider allso the East half of a Gardain near said house, allso A Carpenters Shop turning Lathe \&c and the East part of the wood Shead. and the northardly Half of the barn East of the Great Doors the Half of the bay Widdows thirds Excepted. A Privilage in the barn floor and a Privilage in the wood Yard. In Consideration of Eighteen Dollars paid to us by Timothy Coburn Jr We the above named Sprake Livingstone and Benjamin Livingstone doth Agree to Let Unto Timothy Coburn $\mathrm{J}^{\mathbf{r}}$ his heirs or Assigns the above named Primises and will warrant and Defend the same from all incombenances, for the space of one Year Beginning at the Twenty Second Day of March in the Year 18I3, and Ending the 22d day of March 1814, to have and to hold the Above named Primises with all their Privilages and 


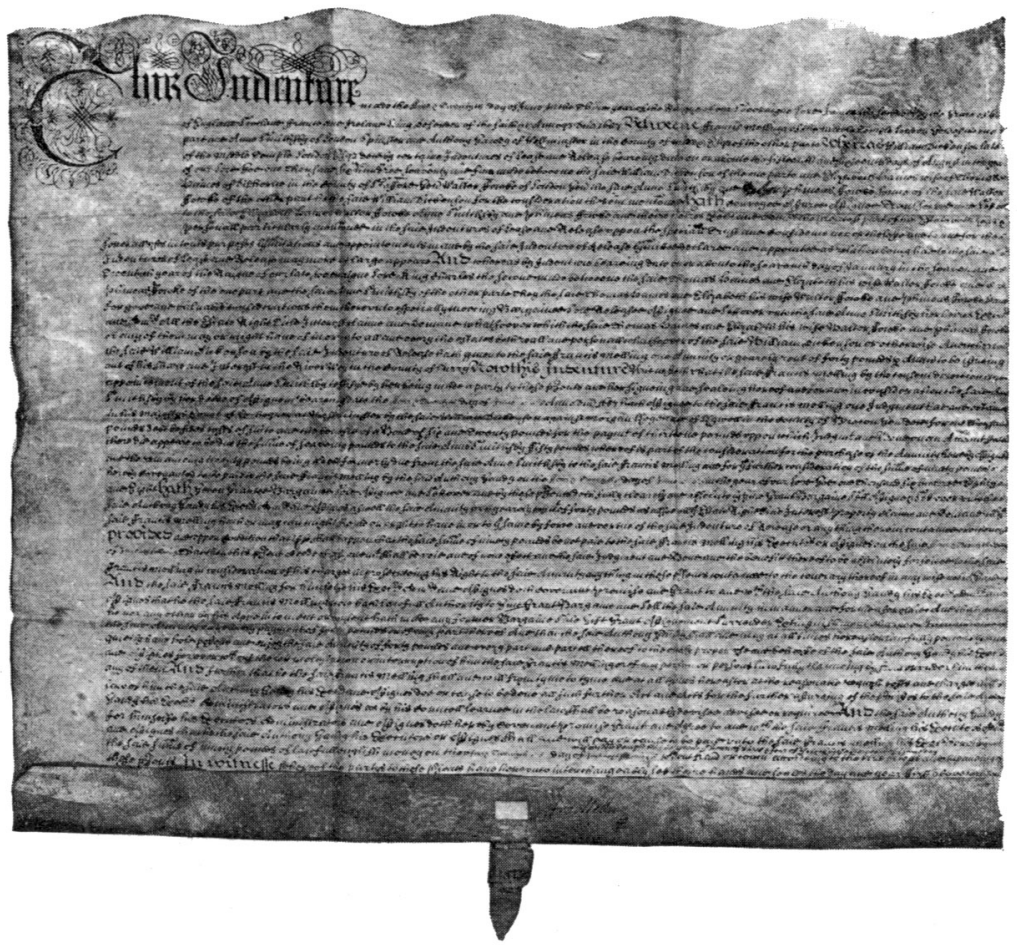

\section{A Seventeenth Century Indenture}


Apertinances there Unto belonging. We the Subscribers have set our hands and seals this I 8 - Day of March in the Year of our Lord one thousands Eight hundred and Thirteen

Attest

Larkin Livingstone

Ephraim Osgood

Note: The lease having terminated and its provisions having been complied with, the signatures of the parties concerned have been clipped out.

The above agreement fairly bristles with the customs of the times and the idiosyncrasies of the language in rural communities in New England. The situation out of which the lease arose is quite clear. The father of the family has died, his two grown sons have inherited the homestead, "widdow's thirds excepted." The mother occupies her third of the house while the sons lease their two thirds to Timothy Coburn, Jr. It has been suggested that the illiterate wording of the document may be explained by the fact that most of those trained in the legal profession at the time of the Revolution were Loyalists who left the country and a new group of lawyers had not yet been trained to take their places.

Among other documents of interest are apprentice agreements. A large collection of such papers would be invaluable in studying labor conditions. The Society has a few of these, but is anxious to add to the number. Other types of business agreements such as articles of copartnership and articles of incorporation the Society is also anxious to preserve.

\section{In fltemoriam}

Charles Curtis Eaton, former librarian of the Graduate School of Business Administration of Harvard University and present assistant dean of the school, died Thursday, March 3, 1932. His death followed an operation resulting from injuries received in the late war in which he served in the front line as lieutenant in the Red Cross Ambulance Corps.

Born in Providence, Rhode Island, January 16, I880, the son of Alice Mary (Dunnell) and Amasa Mason Eaton, he prepared for college at the Cambridge Latin School, and was a member of the class of 1902 of Harvard College. On December 31, I92 I he married Mary Boldt of New York City, who survives him. 